\title{
Meta-analysis of the effect of initial serum protein concentration and empirical prediction model for growth of neonatal Holstein calves through 8 weeks of age
}

\author{
H. G. Bateman II, ${ }^{\star 1}$ T. M. Hill, ${ }^{\star}$ J. M. Aldrich, ${ }^{\star}$ R. L. Schlotterbeck, ${ }^{\star}$ and J. L. Firkins† \\ *Nurture Research Center, Provimi North America, Lewisburg, $\mathrm{OH} 45338$ \\ †Department of Animal Sciences, The Ohio State University, Columbus 43210
}

\begin{abstract}
A data set was constructed from individual calf means gathered in the Nurture Research Center (Lewisburg, $\mathrm{OH}$ ) and used in a meta-analysis to parameterize an empirical model predicting growth measures for neonatal calves. The data set contained 993 observations from 20 research trials conducted in all seasons of multiple years. Growth measures gathered included average daily gain (ADG) preweaning, postweaning, and through 8 wk of age. Independent variables gathered included age at weaning; total starter intake (SI); total milk replacer intake (MRI); milk replacer CP (MRCP) and fat (MRfat) contents; number of days with abnormal fecal scores (AFS); average environmental temperature preweaning, postweaning, and through $8 \mathrm{wk}$ of age; minimum and maximum temperature during the entire 8 wk; body weight at d 0 ; and initial serum protein concentration. Additionally, the interactions of SI, MRI, and MRCP and MRfat were considered for the model. Backward elimination multiple regressions were conducted using a mixed model with a random effect of trial. The final model for total ADG indicated that increasing SI or MRI improves calf growth. Also, increasing MRCP or MRfat increased growth. Increased sickness (as measured by increased AFS) or increased body weight at d 0 decreased ADG. Growth of neonatal dairy calves appears to be more controlled by nutrient intake and their interactions than by surrogates for health status of the calves (AFS and initial serum protein concentration) or environmental temperature. Key words: dairy calf, growth, model, serum protein
\end{abstract}

\section{INTRODUCTION}

Calf health continues to be an enigma for the dairy industry (Gulliksen et al., 2009). Neonatal calves pos-

Received June 1, 2011.

Accepted September 6, 2011.

${ }^{1}$ Corresponding author: gbateman@provimi-na.com sess an innate immune system, and good colostrum feeding and management practices are considered essential for ensuring passive immune transfer (LeBlanc et al., 2006). The 2007 NAHMS Dairy Survey identified and classified numerous practices and methods for feeding colostrum. However, only measurement of total serum protein was reported as an estimate of passive transfer of immunity (USDA, 2010). Of all dairy operations surveyed, only $2.1 \%$ were monitoring serum protein as an estimate of passive transfer. This percentage was greater in large herds (>500 cows) than in smaller herds (USDA, 2010).

Virtala et al. (1996) reported that failure of passive transfer reduced ADG by $48 \mathrm{~g}$ during the first month of life. Similarly, Osorio and Drackley (2010) reported that inadequate colostrum intake reduced calf growth and that this reduction was greater for calves on intensified growth programs compared with conventional growth programs. However, their definition for failure of passive transfer was based on serum IgG content and not total serum protein. Total serum protein can be correlated with serum IgG concentration, and measurement of a serum total protein concentration $>5.2 \mathrm{~g} /$ $\mathrm{dL}$ is often considered indicative of adequate passive transfer of immunity in healthy, well-hydrated calves (McBeath et al., 1971; Weaver et al., 2000). Still, we are unaware of data that indicate a link between total serum protein concentration and growth performance in neonatal dairy calves. Therefore, our objective was to perform a meta-analysis of growth data to determine if serum protein content at d 0 influenced growth in 2- to 3-d-old Holstein bull calves. A secondary objective of this work was to establish an empirical model that predicts calf growth using dietary and environmental descriptors.

\section{MATERIALS AND METHODS}

A data set was constructed using individual observations from research trials conducted by Provimi North America at the Nurture Research Center (Lewisburg, 
$\mathrm{OH})$. Details of these trials have been published previously (Hill et al., 2007a,b,c,d, 2008a,b,c, 2009a,b,c, 2010). In total, the data set contained 993 observations from 20 research trials. All trials used male Holstein calves from a single source. Calves were 2 to $3 \mathrm{~d}$ old at the beginning of each trial.

Data gathered from the trials (Table 1) included initial serum protein concentration; pre- and postweaning ADG; total ADG (0 to $56 \mathrm{~d}$ ); average starter intake over $56 \mathrm{~d}$ (SI); average milk replacer powder intake (MRI, preweaning and over the total trial period of $56 \mathrm{~d}$ ); total number of days with fecal scores $>2$ (AFS); total change in hip width; average, minimum, and maximum temperatures in the calf nursery during each trial both preweaning and over the entire 56-d experimental period; and BW at d 0 (BW0). Additionally, information from each trial to describe the milk replacer protein (MRCP) and fat (MRfat) contents were offered as input variables for the regressions. These descriptive data were used to calculate average daily intake of protein and fat from milk replacers both preweaning and for the entire trial period.

Regression analyses were conducted using a mixed model and SAS software (SAS Institute Inc., Cary, $\mathrm{NC})$. Independent regressions were conducted for ADG pre- and postweaning, total ADG, feed efficiency ( $\mathrm{g}$ of ADG/g of total feed intake), and total change in hip width. Independent terms for each regression were initial serum protein concentration; SI; average daily MRI; AFS; BW0; age at weaning; fat and protein concentrations in the milk replacer powder; average, minimum, and maximum temperature during each trial; average temperature during the preweaning period; and the interactions of MRfat and MRCP, MRI, and SI. Visual inspection of the data set indicated that the relationship between nutrient intakes and some growth measures may not be linear. However, because nutrient intakes are confounded with total feed intake, it is not appropriate to incorporate them into the predictor terms of the model directly and would lead to collinearity of predictors. Therefore, within this analysis, diet nutrient contents were allowed to interact with feed intake to be used as a proxy for nutrient intake. St-Pierre and Glamocic (2000) discussed the use of variance inflation factor (VIF) as a measure of collinearity and concluded that parameter estimability was acceptable when VIF was $<10$. In each regression, the intercept was specified as a random effect, with trial being the subject. For initial regressions, the model included the following linear terms as potential predictors: age at weaning; SI; MRI; MRfat; MRCP; AFS; average temperature preweaning; average, minimum, and maximum temperatures during the entire 56-d trial; BW0; and initial serum protein content. Additional interaction terms in the initial model were SI $\times$ MRI, MRI $\times$ MRCP, MRI $\times$ MRfat, MRI $\times$ MRCP $\times$ MRfat, and MRI $\times$ SI $\times$ MRfat $\times$ MRCP. After initial regressions, terms for nonsignificant $(P>0.05)$ effects were sequentially removed from the model and regressions repeated, with the exception that if a term was a portion of an interaction term, the single (linear) term must remain in the model. This process was repeated until only significant $(P \leq 0.05)$ terms remained in the model. When only significant terms remained in the model, the VIF was

Table 1. Statistical descriptions of variables measured in complete data set

\begin{tabular}{|c|c|c|c|c|c|c|}
\hline Item & Mean & SD & $\mathrm{CV}$ & Kurtosis & Minimum & Maximum \\
\hline Serum protein, $\mathrm{mg} / \mathrm{dL}$ & 5.09 & 0.77 & 15.16 & 1.262 & 3.0 & 8.2 \\
\hline Age at weaning, d & 34.7 & 7.1 & 20.54 & 50.72 & 29 & 49 \\
\hline ADG preweaning, $\mathrm{g} / \mathrm{d}$ & 523 & 133 & 25.3 & -0.099 & 105 & 1,003 \\
\hline ADG postweaning, $\mathrm{g} / \mathrm{d}$ & 840 & 255 & 30.4 & 0.197 & -78 & 1,633 \\
\hline ADG total, $\mathrm{g} / \mathrm{d}$ & 615 & 134 & 21.8 & 0.162 & 129 & 1,161 \\
\hline Starter intake $\mathrm{g} / \mathrm{d}$ & 894 & 242 & 27.1 & -0.161 & 134 & 1,592 \\
\hline $\mathrm{MRI}^{1}$ preweaning, $\mathrm{g} / \mathrm{d}$ & 610 & 136 & 22.3 & -0.094 & 430 & 1,009 \\
\hline MRI total $56 \mathrm{~d}$ trial, $\mathrm{g} / \mathrm{d}$ & 405 & 127 & 31.3 & 1.066 & 216 & 882 \\
\hline Feed efficiency, $g$ of DMI/g of ADG & 0.42 & 0.072 & 17.2 & 2.204 & 0.13 & 0.83 \\
\hline Abnormal fecal score days & 4.7 & 4.5 & 97.23 & 2.225 & 0 & 34 \\
\hline Hip width change, $\mathrm{cm}$ & 4.09 & 1.02 & 24.95 & 0.0875 & 0.8 & 9.5 \\
\hline $\mathrm{MR}^{1} \mathrm{CP}$ content, $\mathrm{g} / 100 \mathrm{~g}$ & 24.9 & 2.4 & 9.60 & -0.058 & 20 & 28 \\
\hline MR fat content, $\mathrm{g} / 100 \mathrm{~g}$ & 17.7 & 1.4 & 7.78 & 1.504 & 17 & 22 \\
\hline MR CP intake, g & 5,409 & 2,256 & 41.71 & 1.012 & 2,415 & 13,837 \\
\hline MR fat intake, $\mathrm{g}$ & 3,844 & 1,573 & 40.93 & 1.297 & 2,045 & 9,884 \\
\hline MR CP intake, $\mathrm{g} / \mathrm{d}$ & 153 & 42.2 & 27.53 & 0.048 & 86 & 282 \\
\hline MR fat intake, $\mathrm{g} / \mathrm{d}$ & 108 & 26.3 & 24.38 & 1.399 & 73 & 202 \\
\hline Mean temperature preweaning, ${ }^{\circ} \mathrm{C}$ & 9.2 & 8.8 & 95.88 & -0.472 & -8 & 25.6 \\
\hline Mean temperature, ${ }^{\circ} \mathrm{C}$ & 8.8 & 8.8 & 92.82 & -0.595 & -5 & 24.4 \\
\hline Minimum temperature, ${ }^{\circ} \mathrm{C}$ & -7.8 & 9.7 & -124.9 & -0.635 & -25 & 11.7 \\
\hline Maximum temperature, ${ }^{\circ} \mathrm{C}$ & 27.6 & 5.6 & 20.22 & -0.978 & 18.9 & 37.2 \\
\hline BW at wk $0, \mathrm{~kg}$ & 42.9 & 5.5 & 12.76 & 0.037 & 27.3 & 63.8 \\
\hline
\end{tabular}

${ }^{1} \mathrm{MRI}=$ average milk replacer powder intake, $\mathrm{MR}=$ milk replacer powder. 
calculated. When the VIF was greater than the a priori selected cut point of 10 , the variable with the smallest $F$-value was removed, the model reparameterized with the reduced set of predictors (St-Pierre and Glamocic, 2000), and the process repeated. This cyclic process was continued until the VIF was $<10$, at which time the models were considered adequately parameterized.

Although serum protein measurements are a continuous variable, the variation in its measure (Table 1 ) may interfere with detecting the influence on growth of neonatal calves. Within the data set used for model development, serum protein content had a CV of over $15 \%$. Similarly, Nocek et al. (1984) reported serum protein measures where the SE was up to $10 \%$ of the reported means. Therefore, serum proteins were classified as poor, marginal, or adequate. Poor serum protein was $<5.0 \mathrm{mg} / \mathrm{dL}$, marginal serum protein was $\geq 5.0 \mathrm{mg} / \mathrm{dL}$ and $\leq 5.5 \mathrm{mg} / \mathrm{dL}$, and adequate serum protein was $>5.5$ $\mathrm{mg} / \mathrm{dL}$. All regression procedures were repeated except that the continuous variable serum protein was dropped from the list of independent variables considered and was replaced with the corresponding categorical value.

Sensitivity and directionality of predictions from the final models were evaluated. Directionality was evaluated by systematically increasing each input $10 \%$ from the mean value within the data set and expressing the resulting output as the percentage change after the increase compared with the mean predicted value. Monte Carlo simulation of each input variable was also used to evaluate the relative sensitivity of the model to changes in the input variables. A series of 400 random estimates of the input parameter centered on the observed mean with the observed SD (Table 1) were generated using Microsoft Excel (Microsoft Corp., Redmond, WA). These were then used to produce model predicted outputs. The CV of the predictions were compared within a model to evaluate which input parameters had the greatest influence on predictions.

\section{RESULTS AND DISCUSSION}

Descriptive statistics for variables in the data set are presented in Table 1. Calf ADG averaged $615 \mathrm{~g}$ across the 20 research trials. All trials reported that calves appeared to be in good health. Initial serum proteins averaged $5.09 \mathrm{mg} / \mathrm{dL}$. The AFS averaged 4.67 over the 20 research trials. A variety of milk replacer powders was fed, with protein contents ranging from 20 to 28 $\mathrm{g} / 100 \mathrm{~g}$ (as-fed basis) and a small kurtosis value indicating wide spread of values within the data. However, fat content of the MR powders ranged from 17 to 22 $\mathrm{g} / 100 \mathrm{~g}$ (as-fed basis) with a larger kurtosis value. Inspection of the descriptive statistics indicates that a large proportion of the calves were fed MR powders with fat content near the mean of $17.7 \mathrm{~g} / 100 \mathrm{~g}$. Mean environmental temperature during the 20 research trials was $8.8^{\circ} \mathrm{C}$, whereas the mean minimum temperature was $-7.8^{\circ} \mathrm{C}$ and the mean maximum temperature was $27.6^{\circ} \mathrm{C}$.

Different predictors were retained for each dependent growth response variable (Table 2). All variables that remained in the various prediction models were significantly different from zero at $P<0.05$. Fit statistics for each model are presented in Table 3 and the sensitivity of each model to a $10 \%$ increase in independent variables is presented in Table 4 . Using the means of the predictors (Table 1 ) as inputs, the models predict mean ADG of $657 \mathrm{~g} / \mathrm{d}$ preweaning, $884 \mathrm{~g} / \mathrm{d}$ postweaning, and $741 \mathrm{~g} / \mathrm{d}$ over the $56 \mathrm{~d}$ of the trials (Table 4). Additionally, they predict a mean feed efficiency of $0.42 \mathrm{~g}$ of $\mathrm{ADG} / \mathrm{g}$ of total feed intake over the $56-\mathrm{d}$ trials and 4.1-cm increase in hip width over the $56-\mathrm{d}$ trials. Initial serum protein as a continuous variable was not a significant predictor for any growth measure. When initial serum protein concentration was classified as poor, marginal, or adequate, it was a significant predictor for postweaning ADG and total 56-d feed efficiency. However, the improvements of these model fit statistics were small and not easily understood because predictions of preweaning measures were not improved. It is assumed that the addition of initial serum protein classes as a significant predictor is not biologically relevant and therefore it is not discussed further.

Increasing nutrient intake (SI, MRI, MRCP, MRfat) improved all growth measures (Table 4). The positive relationship between MRfat and growth was not expected. Previous reports from our research unit have reported decreased starter intake when milk replacer fat content was increased (Hill et al., 2009e); when fat content of the MR powder alone was evaluated against ADG, this relationship held within the data set (Figure 1; Hill et al., 2006b). Inspection of the data (Table 1) shows that MR fat content and MR fat intake both had high kurtosis values, indicating relatively sharp distribution functions. The mean MR fat content was also very close to the minimum MR fat content, seemingly indicating some skew to the data distribution. This may have affected our regression analysis by limiting the range of data used for the analysis. However, our group routinely reports increased growth from increased SI (Hill et al., 2009d), MRI (Hill et al., 2006b), or MRCP (Hill et al., 2006a) when evaluated within the range represented in this data set (Table 1).

Model sensitivities presented in Table 4 show the relative importance of SI in determining the growth of neonatal calves. For all growth measures evaluated, small increases in SI resulted in approximately the same proportional increase in growth. However, this was not 
Table 2. Coefficients $( \pm \mathrm{SE})$ of multiple regression analysis equations predicting growth measures in calves fed milk replacer and starter when initial serum protein concentration was considered as a continuous variable ${ }^{1}$

\begin{tabular}{|c|c|c|c|c|c|}
\hline Parameter $^{2}$ & $\begin{array}{l}\text { Preweaning } \\
\text { ADG, g/d }\end{array}$ & $\begin{array}{l}\text { Postweaning } \\
\text { ADG, g/d }\end{array}$ & $\begin{array}{c}\text { Total } \\
\text { ADG, g/d }\end{array}$ & $\begin{array}{c}\text { Feed } \\
\text { efficiency, } \mathrm{g} / \mathrm{g}\end{array}$ & $\begin{array}{l}\text { Hip width } \\
\text { change, cm }\end{array}$ \\
\hline Intercept & $-3,201(583)$ & $-1,785(621)$ & $-2,618(509)$ & $0.365(0.033)$ & $-5.06(2.32)$ \\
\hline Wean, d & $-2.67(1.1)$ & $11.4(2.3)$ & - & $0.00236(0.00054)$ & - \\
\hline SI, g/d & $0.496(0.047)$ & $0.460(0.089)$ & $0.430(0.041)$ & $0.000049(0.000008)$ & $0.00300(0.00011)$ \\
\hline MRI, g/d & $5.72(1.13)$ & $2.16(0.98)$ & $4.26(1.0)$ & - & $0.0182(0.0043)$ \\
\hline MRCP, g/100 g & $55.8(9.17)$ & $22.1(8.4)$ & $44.7(7.9)$ & $0.00352(0.00083)$ & $0.159(0.038)$ \\
\hline MRfat, $\mathrm{g} / 100 \mathrm{~g}$ & $114.1(21.3)$ & $75.6(28.2)$ & $96.5(18.8)$ & - & $0.258(0.10)$ \\
\hline AFS, d & $-2.64(0.8)$ & - & $-2.34(0.68)$ & $-0.00174(0.00052)$ & $-0.0186(0.0066)$ \\
\hline Avg Temp, ${ }^{\circ} \mathrm{C}$ & $-5.17(2.0)$ & - & - & - & - \\
\hline Min Temp, ${ }^{\circ} \mathrm{C}$ & $4.16(1.6)$ & - & - & - & - \\
\hline Temp preweaning, ${ }^{\circ} \mathrm{C}$ & & $-6.99(2.88)$ & - & - & - \\
\hline BW0, kg & $-5.93(0.5)$ & - & $-4.80(0.45)$ & $-0.00339(0.00033)$ & $-0.0777(0.0043)$ \\
\hline $\mathrm{SI} \times \mathrm{MRI}$ & $0.0159(0.003)$ & $0.00200(0.0006)$ & $0.0120(0.0028)$ & - & \\
\hline $\mathrm{MIR} \times \mathrm{MRCP}$ & $-0.0694(0.02)$ & - & $-0.0440(0.018)$ & - & $-0.00027(0.0001)$ \\
\hline MRI $\times$ MRfat & $-0.175(0.04)$ & $-0.144(0.05)$ & $-0.150(0.035)$ & - & $-0.00046(0.0002)$ \\
\hline $\mathrm{SI} \times \mathrm{MRI} \times \mathrm{MRCP}$ & $-0.00061(0.0001)$ & $-0.00006(0.00002)$ & $-0.00045(0.00011)$ & - & - \\
\hline $\mathrm{SI} \times \mathrm{MRI} \times$ MRfat & $-0.00080(0.0002)$ & - & $-0.00057(0.00015)$ & - & - \\
\hline $\mathrm{SI} \times \mathrm{MRI} \times \mathrm{MRCP} \times \mathrm{MRfat}$ & $0.000031(0.000007)$ & - & $0.000022(0.000006)$ & - & - \\
\hline
\end{tabular}

${ }^{1}$ Blank spaces in the table indicate variables that were significant predictors for one dependent variable but were not significant predictors for other dependent variables. All predictor variables were significant at $P<0.05$.

${ }^{2}$ Wean = age at weaning; SI = starter intake; MRI = milk replacer powder intake; $\mathrm{MRCP}=$ milk replacer powder protein content; MRfat $=$ milk replacer powder fat content; AFS = days with fecal scores $>2$; Avg Temp = average temperature in the calf nursery; Min Temp = minimum temperature in the calf nursery; Temp preweaning = average temperature in the calf nursery during the preweaning period; BW0 $=$ initial BW.

the case for increased MRI or MRCP because neither of these variables had large influences on postweaning ADG. All models predict reduced growth when AFS or BW0 increases. Increasing BW0 implies an increased maintenance requirement of the young calf (NRC, 2001) with no concomitant increase in nutrient intakes. It is possible that when milk replacer powder is fed in amounts that are proportional to body weight, this relationship will not occur. However, the common practice in the United States is to feed milk replacer powder at a constant amount per calf per day. When calves are sick (AFS) energy is required to be partitioned to the immune system instead of growth (Martin et al., 2003).

The CV of model predictions presented in Table 5 corroborates the sensitivities presented in Table 4. For all models, other than prediction of feed efficiency, variation in starter intake resulted in the largest variation in predictions showing the relative importance in accurately measuring starter intake. Variation in most other inputs (notable exceptions for milk replacer powder intake when estimating preweaning or total ADG) resulted in small CV of the predictions. Although each of the variables evaluated were retained as significant predictors, varying their input values resulted in $\mathrm{CV}$ of less than $10 \%$. This may indicate that accurate measurement of these input variables is not as important as accurate measurement of total feed intake (starter and milk replacer powder) when predicting growth of neonatal calves.

The NRC (2001) has a modifier that predicts reduced calf growth when environmental temperature is below $15^{\circ} \mathrm{C}$. Data summarized in this report were collected across a variety of environmental temperatures (range -25 to $38^{\circ} \mathrm{C}$, mean $9^{\circ} \mathrm{C}$; Table 1 ). Within this data set, as temperature increased, ADG decreased although not significantly (Figure 2). In a summary of 572 calves reared in the University of Minnesota calf facility, Chester-Jones et al. (2008) reported reduced starter intake during May through September compared with that in other months of the year. Similarly, McKnight (1978) reported reduced starter intakes and lower ADG of calves in summer compared with winter or fall. Place et al. (1998) reported that calves born in spring, summer, or fall had reduced ADG from birth to 4 mo of age when compared with calves born in winter.

One of our objectives was to establish an empirical equation that predicted calf growth over the entire nursery phase of life. Starter intake during the 56-d growth period had the greatest effect on ADG and hip width change. This agrees with our data (Bateman et al., 2009). We reported that starter intake was the only

Table 3. Fit statistics for prediction models

\begin{tabular}{lccc}
\hline $\begin{array}{l}\text { Model } \\
\text { dependent variable }\end{array}$ & $\begin{array}{c}\text { Log-likelihood } \\
\mathrm{R}^{2}\end{array}$ & $\begin{array}{c}\text { Variance } \\
\text { inflation } \\
\text { factor }\end{array}$ & $\mathrm{CV}$ \\
\hline Preweaning ADG, g/d & 0.84 & 6.37 & 14.0 \\
Postweaning ADG, g/d & 0.65 & 2.84 & 18.2 \\
Total ADG, g/d & 0.89 & 8.94 & 10.3 \\
Feed efficiency, g/g & 0.21 & 1.27 & 11.4 \\
Hip width change, cm & 0.70 & 3.01 & 15.0 \\
\hline
\end{tabular}




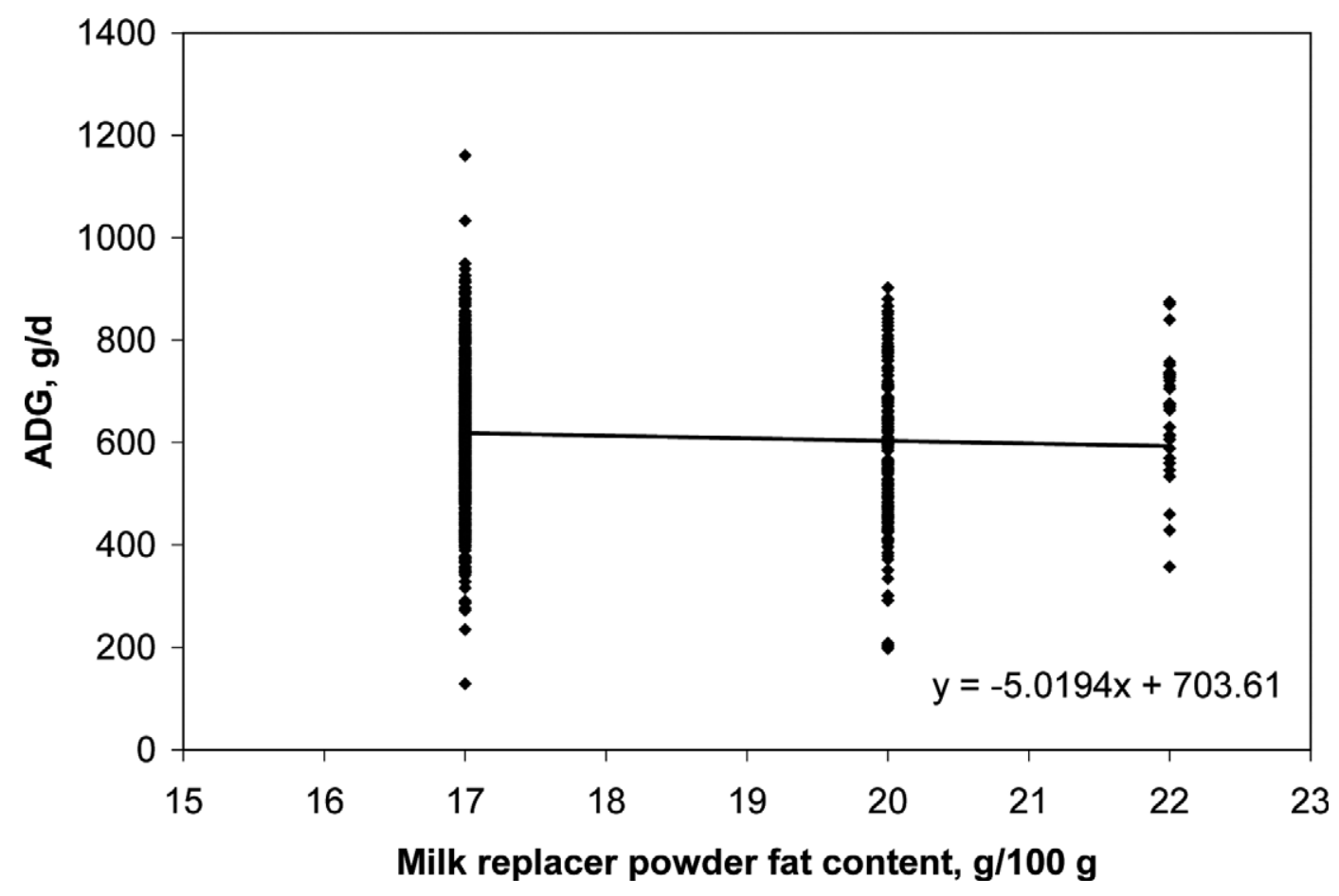

Figure 1. Relationship between milk replacer powder fat content and ADG of calves over the first 8 wk of age.

factor relating to $\mathrm{ADG}$ of calves from zero to $12 \mathrm{wk}$ of age when milk replacer intake was held constant. The predicted improvements in growth from increasing starter intake were followed closely by that when MR intake increased. This was not surprising as others have indicated that increased MR intake results in increased ADG (Raeth-Knight et al., 2009). The relative decreases (Table 4) in growth measures over the first $56 \mathrm{~d}$ of life due to increased initial BW were similar and were quite large relative to the decreases in $\mathrm{ADG}$ postweaning. This implies that most of the loss comes from meeting the maintenance requirements of these calves before they begin consuming large amounts of starter feed.

Others (Tozer and Heinrichs, 2001; Heinrichs et al., 2005) have attempted to quantify factors influencing time to first calving of dairy heifers. Tozer and Heinrichs (2001) evaluated herd-level factors to determine

Table 4. Proportional change of model predictions to $10 \%$ increases in individual parameter inputs with other input parameters held constant at mean of observed data used for model development ${ }^{1}$

\begin{tabular}{|c|c|c|c|c|c|}
\hline Parameter $^{2}$ & $\begin{array}{c}\text { Preweaning } \\
\text { ADG }\end{array}$ & $\begin{array}{c}\text { Postweaning } \\
\text { ADG }\end{array}$ & $\begin{array}{l}\text { Total } \\
\text { ADG }\end{array}$ & $\begin{array}{c}\text { Feed } \\
\text { efficiency }\end{array}$ & $\begin{array}{l}\text { Hip width } \\
\text { change }\end{array}$ \\
\hline Wean & -1.41 & 4.18 & - & 1.93 & - \\
\hline SI & 7.93 & 6.98 & 7.44 & 1.03 & 6.58 \\
\hline MRI & 6.76 & 0.69 & 5.03 & - & 3.33 \\
\hline MRCP & 2.03 & 0.13 & 1.59 & 2.06 & 3.04 \\
\hline MRfat & 8.93 & 3.72 & 6.60 & - & 3.09 \\
\hline AFS & -0.19 & -0.06 & -0.15 & -0.19 & -0.21 \\
\hline Temp preweaning & - & -0.72 & - & - & - \\
\hline Min Temp & -0.49 & - & - & - & - \\
\hline Avg Temp & -0.69 & - & - & - & - \\
\hline BW0 & -3.87 & -0.98 & -5.84 & -3.43 & -8.16 \\
\hline Predicted mean ${ }^{3}$ & 656.7 & 884.1 & 740.7 & 0.424 & 4.08 \\
\hline
\end{tabular}

${ }^{1}$ Blank spaces in the table indicate variables that were significant predictors for one dependent variable but were not significant predictors for other dependent variables.

${ }^{2}$ Wean = age at weaning; $\mathrm{SI}=$ starter intake; $\mathrm{MRI}=$ milk replacer powder intake; $\mathrm{MRCP}=$ milk replacer powder protein content; MRfat = milk replacer powder fat content; AFS = days with fecal scores $>2 ;$ Avg Temp $=$ average temperature in the calf nursery; Min Temp = minimum temperature in the calf nursery; Temp preweaning $=$ average temperature in the calf nursery during the preweaning period; $\mathrm{BW} 0=$ initial $\mathrm{BW}$.

${ }^{3}$ Predicted value of dependent variable at mean of independent variables within the data set. 
Table 5. Coefficient of variation of 400 model predictions when individual input variables were randomly selected from a population with mean and SD equal to that which describes the data set used to design the model while other input variables were held constant at the observed mean of the data $\operatorname{set}^{1}$

\begin{tabular}{lccccc}
\hline \multicolumn{5}{c}{ Model dependent variable } \\
\cline { 2 - 5 } Parameter $^{2}$ & $\begin{array}{c}\text { Preweaning } \\
\text { ADG }\end{array}$ & $\begin{array}{c}\text { Postweaning } \\
\text { ADG }\end{array}$ & $\begin{array}{c}\text { Total } \\
\text { ADG }\end{array}$ & $\begin{array}{c}\text { Feed } \\
\text { efficiency }\end{array}$ & $\begin{array}{c}\text { Hip width } \\
\text { change }\end{array}$ \\
\hline Wean & 2.90 & 8.40 & - & 4.01 & - \\
SI & 21.79 & 17.24 & 19.42 & 2.83 & 16.62 \\
MRI & 21.16 & 2.33 & 15.79 & - & 9.58 \\
MRCP & 1.85 & 0.12 & 1.41 & 1.95 & 2.93 \\
MRfat & 6.73 & 2.87 & 5.36 & - & 2.51 \\
AFS & 2.00 & 0.54 & 1.37 & -1.94 & - \\
Temp preweaning & - & 6.98 & - & - & - \\
Min Temp & 6.69 & - & - & - & - \\
Avg Temp & 6.35 & - & -3.32 & 4.16 & 10.68 \\
BW0 & 5.17 & 1.30 & & -
\end{tabular}

${ }^{1}$ Blank spaces in the table indicate variables that were significant predictors for one dependent variable but were not significant predictors for other dependent variables.

${ }^{2}$ Wean = age at weaning; $\mathrm{SI}=$ starter intake; MRI = milk replacer powder intake; $\mathrm{MRCP}=$ milk replacer powder protein content; MRfat $=$ milk replacer powder fat content; AFS $=$ days with fecal scores $>2$; Avg Temp = average temperature in the calf nursery; Min Temp = minimum temperature in the calf nursery; Temp preweaning $=$ average temperature in the calf nursery during the preweaning period; BW0 $=$ initial $\mathrm{BW}$.

economic responses to management factors and reported that herd culling rate and age at first calving had the greatest influence on the economics of raising herd replacements. However, they (Tozer and Heinrichs, 2001) did not evaluate individual management practices that influence age at first calving. Heinrichs et al. (2005) evaluated multiple management practices to determine which were related to age, BW, BCS, and wither height at first calving. They reported very few significant predictors for any of these growth measures. However, their measures were all collected during the first 4 mo of age (similar to the current study) but were used in an attempt to predict events that occur much later in the life of the calf. Place et al. (1998) reported a 0.26-kg increase in BW for every 1-kg increase in DMI during the first $4 \mathrm{mo}$ of life. Other nutritional factors

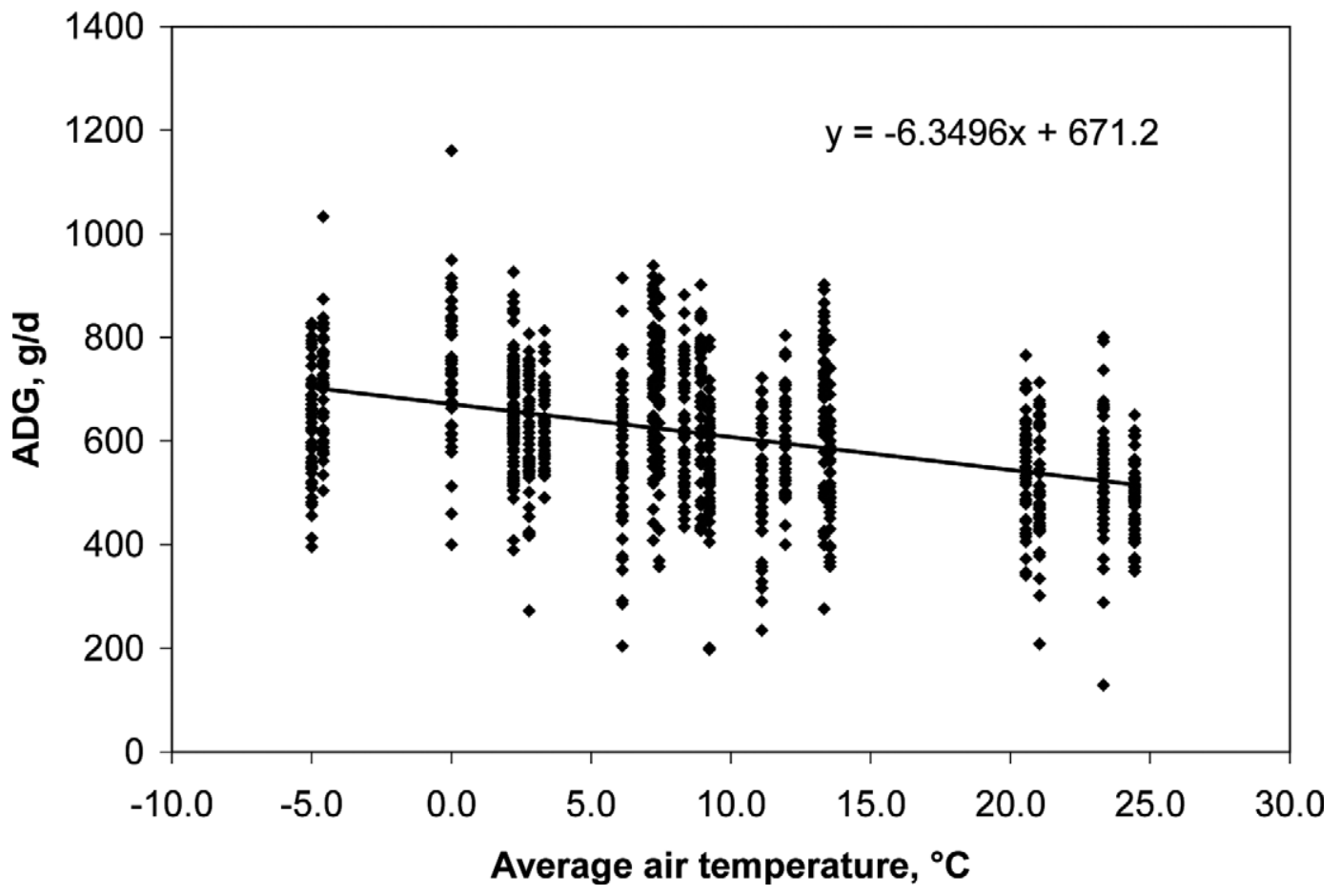

Figure 2. Relationship between average air temperature inside an unheated, naturally ventilated calf nursery located in southwestern Ohio and ADG of neonatal calves over the first 8 wk of age.

Journal of Dairy Science Vol. 95 No. 1, 2012 
including amount of colostrum fed, grain intake, and milk intake were not retained as significant predictors (Place et al., 1998).

\section{CONCLUSIONS}

Initial serum protein content measured by refractometer was not a significant predictor of neonatal growth in dairy calves. However, when classified as poor, marginal, or adequate, as related to estimates of passive transfer of immunity, initial serum protein was a significant predictor of postweaning ADG and overall feed efficiency yet addition of this variable only slightly improved the ability of the models to predict growth of neonatal calves. Intake of starter feed and milk replacer powder were the most important variables for predicting growth in these calves.

\section{REFERENCES}

Bateman, H. G. II, T. M. Hill, J. M. Aldrich, and R. L. Schlotterbeck. 2009. Effects of corn processing, particle size, and diet form on performance of calves in bedded pens. J. Dairy Sci. 92:782-789.

Chester-Jones, H., D. M. Ziegler, R. Larson, C. Soderholm, S. Hayes, J. G. Linn, M. Raeth-Knight, G. Golombeski, and N. Broadwater. 2008. Applied calf research from birth to six months. Pages 106-112 in Proc. State Dairy Nutrition and Management Conf., Dubuque, IA. Iowa State University Press, Ames.

Gulliksen, S. M., K. I. Lie, and O. Osteras. 2009. Calf health monitoring in Norwegian dairy herds. J. Dairy Sci. 92:1660-1669.

Heinrichs, A. J., B. S. Heinrichs, O. Harel, G. W. Rogers, and N. T. Place. 2005. A prospective study of calf factors affecting age, body size, and body condition score at first calving of Holstein dairy heifers. J. Dairy Sci. 88:2828-2835.

Hill, T. M., J. M. Aldrich, R. L. Schlotterbeck, and H. G. Bateman II.. 2006a. Effects of feeding calves different rates and protein concentrations of twenty percent fat milk replacers on growth during the neonatal period. Prof. Anim. Sci. 22:252-260.

Hill, T. M., J. M. Aldrich, R. L. Schlotterbeck, and H. G. Bateman II.. 2006b. Effects of feeding rate and concentrations of protein and fat of milk replacers fed to neonatal calves. Prof. Anim. Sci. 22:374-381.

Hill, T. M., J. M. Aldrich, R. L. Schlotterbeck, and H. G. Bateman II. 2007a. Effects of changing the fatty acid composition of calf starters. Prof. Anim. Sci. 23:665-671.

Hill, T. M., J. M. Aldrich, R. L. Schlotterbeck, and H. G. Bateman II. 2007b. Protein concentrations for starters fed to transported neonatal calves. Prof. Anim. Sci. 23:123-134.

Hill, T. M., H. G. Bateman II, J. M. Aldrich, and R. L. Schlotterbeck. 2007c. Effects of feeding rate of milk replacers and bedding material for calves in a cold, naturally ventilated nursery. Prof. Anim. Sci. 23:656-664.

Hill, T. M., H. G. Bateman II, J. M. Aldrich, and R. L. Schlotterbeck. 2007d. Effects of the feeding rate of high protein calf milk replacers. Prof. Anim. Sci. 23:649-655.

Hill, T. M., H. G. Bateman II, J. M. Aldrich, and R. L. Schlotterbeck. 2008a. Effects of using wheat gluten and rice protein concentrate in dairy calf milk replacers. Prof. Anim. Sci. 24:465-472.

Hill, T. M., H. G. Bateman II, J. M. Aldrich, and R. L. Schlotterbeck. 2008b. Effects of the amount of chopped hay or cottonseed hulls in a textured calf starter on young calf performance. J. Dairy Sci. 91:2684-2693.
Hill, T. M., H. G. Bateman II, J. M. Aldrich, and R. L. Schlotterbeck. 2009a. Effect of weaning age of dairy calves fed a conventional or more optimum milk replacer program. Prof. Anim. Sci. 25:619-624.

Hill, T. M., H. G. Bateman II,, J. M. Aldrich, and R. L. Schlotterbeck. 2009b. Effects of changing the essential and functional fatty acid intake of dairy calves. J. Dairy Sci. 92:670-676.

Hill, T. M., H. G. Bateman II, J. M. Aldrich, and R. L. Schlotterbeck. 2009c. Optimizing nutrient ratios in milk replacers for calves less than five weeks of age. J. Dairy Sci. 92:3281-3291.

Hill, T. M., H. G. Bateman II, J. M. Aldrich, and R. L. Schlotterbeck. 2009d. Roughage for diets fed to weaned dairy calves. Prof. Anim. Sci. 25:283-288.

Hill, T. M., H. G. Bateman II, J. M. Aldrich, and R. L. Schlotterbeck. 2009e. Effects of fat concentration of a high-protein milk replacer on calf performance. J. Dairy Sci. 92:5147-5153.

Hill, T. M., H. G. Bateman II, J. M. Aldrich, and R. L. Schlotterbeck. 2010. Effect of milk replacer program on digestion of nutrients in dairy calves. J. Dairy Sci. 93:1105-1115.

Hill, T. M., H. G. Bateman II, J. M. Aldrich, R. L. Schlotterbeck, and K. G. Tanan. 2008c. Optimal concentrations of lysine, methionine, and threonine in milk replacers for calves less than five weeks of age. J. Dairy Sci. 91:2433-2442.

LeBlanc, S. J., K. D. Lissemore, D. F. Kelton, T. F. Duffield, and K. E. Leslie. 2006. Major advances in disease prevention in dairy cattle. J. Dairy Sci. 89:1267-1279.

Martin, L. B., A. Scheuerlein, and M. Wikelski. 2003. Immune activity elevates energy expenditure of house sparrows: A link between direct and indirect costs? Proc. R. Soc. Lond. B Biol. Sci. 270:153-158

McBeath, D. G., W. J. Penhale, and E. F. Logan. 1971. An examination of the influence of husbandry on the plasma immunoglobulin content. Vet. Rec. 88:266-270.

McKnight, D. R. 1978. Performance of newborn dairy calves in hutch housing. Can. J. Anim. Sci. 58:517-520.

Nocek, J. E., D. G. Braund, and R. G. Warner. 1984. Influence of neonatal colostrum administration, immunoglobulin, and continued feeding of colostrum on calf gain, health, and serum protein. J. Dairy Sci. 67:319-333.

NRC. 2001. Nutrient Requirements of Dairy Cattle. 7th rev. ed. National Academy Press, Washington, DC.

Osorio, J. S., and J. K. Drackley. 2010. Inadequate colostrum intake decreases growth of calves on intensified feeding programs. Pages 18-19 in Proceedings 2010 Illinois Dairy Days. University of Illinois, Urbana.

Place, N. T., A. J. Heinrichs, and H. N. Erb. 1998. The effects of disease, management, and nutrition on average daily gain of dairy heifers from birth to four months. J. Dairy Sci. 81:1004-1009.

Raeth-Knight, M., H. Chester-Jones, S. Hayes, J. Linn, R. Larson, D. Ziegler, B. Ziegler, and N. Broadwater. 2009. Impact of conventional or intensive milk replacer programs on Holstein heifer performance through six months of age and during first lactation. J. Dairy Sci. 92:799-809.

St-Pierre, N. R., and D. Glamocic. 2000. Estimating unit costs of nutrients from market prices of feedstuffs. J. Dairy Sci. 83:1402-1411.

Tozer, P. R., and A. J. Heinrichs. 2001. What affects the cost of raising replacement dairy heifers: A multiple-component analysis. J. Dairy Sci. 84:1836-1844.

USDA. 2010. Dairy 2007, Heifer Calf Health and Management Practices on U.S. Dairy Operations, 2007 USDA:APHIS:VS, CEAH, Fort Collins, CO.

Virtala, A.-M. K., G. D. Mechor, Y. T. Grohn, and H. N. Erb. 1996. The effect of calfhood diseases on growth of female dairy calves during the first 3 months of life in New York State. J. Dairy Sci. 79:1040-1049.

Weaver, D. M., J. W. Tyler, D. C. VanMetre, D. E. Hostetler, and G. M. Barrington. 2000. Passive transfer of colostral immunoglobulins in calves. J. Vet. Intern. Med. 14:569-577. 